\title{
Life Satisfaction, and Anxiety Levels among University Students
}

\author{
George Tsitsas ${ }^{1}$, Panagiotis Nanopoulos ${ }^{2}$, Antonia Paschali ${ }^{*}$ \\ ${ }^{1}$ Counseling Center, Harokopio University, Athens, Greece \\ ${ }^{2}$ Athens University of Economics and Business, Athens, Greece \\ ${ }^{3}$ Faculty of Nursing, School of Health Sciences, National \& Kapodistrian University of Athens, Athens, Greece \\ Email: gtsitsas@hua.gr, pnanop@aueb.gr, anpascha@nurs.uoa.gr
}

How to cite this paper: Tsitsas, G., Nanopoulos, P., \& Paschali, A. (2019). Life Satisfaction, and Anxiety Levels among University Students. Creative Education, 10, 947-961.

https://doi.org/10.4236/ce.2019.105071

Received: February 11, 2019

Accepted: May 18, 2019

Published: May 21, 2019

Copyright $\odot 2019$ by author(s) and Scientific Research Publishing Inc. This work is licensed under the Creative Commons Attribution International License (CC BY 4.0).

http://creativecommons.org/licenses/by/4.0/

\begin{abstract}
University or College years seem to be a stressful time for students due to many challenges: academic, personal adjustment to a new life, and socially building new friendships. Life satisfaction is considered one of the basic components of psychological well-being. Studies have supported that lower levels of life satisfaction have been related to high levels of anxiety. Also the constructs of assertiveness and empathy seem to be related with life satisfaction. The present study compares $1^{\text {st }}$ and $4^{\text {th }}$-year undergraduate students in relation to variables such as life satisfaction (The Life Satisfaction Index), stress, (STAI) assertiveness (Rathus Assertiveness Schedule) and empathy (Interpersonal Reactivity Index (IRI)). The participants were in total $410,1^{\text {st }}$ year $(\mathrm{N}=205)$ and $4^{\text {th }}$ year $(\mathrm{N}=205)$ undergraduate students. All findings are discussed in detail; some main results showed that: 1) Independently of sex students had similar anxiety levels; life satisfaction was significantly higher among those with low state anxiety but not with low trait anxiety; 2) Trait anxiety score analysis revealed nonsignificant results; 3) Young women are more life satisfied compared to young men among $1^{\text {st }}$ year students; 4) The percent of students with high life satisfaction is significantly higher among those that grew up in urban and semi-urban regions compared to those that grew up in other regions. The findings of the present study emphasize the need to explore ways to help undergraduate students to adjust during their academic years and life at the University.
\end{abstract}

\section{Keywords}

University Students, Life Satisfaction, Stress, Assertiveness, Empathy

\section{Introduction}

University years, can be considered as a period of negotiation with new aca*Contribute equally. 
demic and personal challenges (Rickinson, 1998). During this period, students face challenges such as separation from their family and friends, dealing with rules, and building relationships. Arnett (2000) names this period "emerging adulthood". One of the main issues in this period is the threat to students' emotional well-being and psychological distress of adjusting to a new life (Roberts \& Zelenyanski, 2002). Therefore, University years are considered to be as one of the most stressful periods (Cress \& Lampman, 2007; Chao, 2012).

Life satisfaction seems to be a basic construct in the aspect of psychological (or subjective) well-being (Diener, Lucas, \& Oishi, 2002).

According to a study by Diener (2000) college students from 17 different countries, revealed that happiness and life satisfaction are more important than money for most college students. In another study, it was observed that financial stress did not significantly predict life satisfaction (Chow, 2005). Life satisfaction is related with optimism (Extremera et al., 2009), academic performance, self-image (Chow, 2005), physical health, social relationships (Chow, 2005; Darling, McWey, Howard, \& Olmstead, 2007). Furthermore studies have supported that lower levels of life satisfaction have been related to high levels of anxiety (Bourland, Stanley, Snyder, Novy, Beck, Averill, \& Swann, 2000; Cook, Black, Rabins, \& German, 2000; Headey, Kelley, \& Wearing, 1993; Honkalampi, Saarinen, Hintikka, Virtanen, \& Viinamaeki, 1999). Additionally, in a preliminary study performed by the authors (Paschali \& Tsistas, 2010), on a sample of 200 University students, we found that the majority of participants (63.4\%) were found to have low "life satisfaction" without any differences between the two sexes. Analysis of STAI showed that students with low scores in State anxiety have high scores in life satisfaction, whereas high scores in State, have low scores in life satisfaction. Furthermore Trait Anxiety score analysis revealed nonsignificant results. Also it was found that the mean score in life satisfaction of students during the 1 st year was statistically significantly lower as compared to $4^{\text {th }}$ year students.

Assertiveness is considered to be a skill of interpersonal communication, essential in human relationships (Ellis \& Hartley, 2005), clearly differentiated from aggressive behaviour, and from indirectly aggressive behaviour, non-assertive or pathetic behaviour (Lange \& Jakubowski, 1976). It is well known that assertiveness is related with life satisfaction i.e. when students have high scores in assertiveness which correlates with high scores in life satisfaction (Veenhoven, 1996). Anxiety has a negative impact on well-being and life satisfaction seems to be highly related with life satisfaction among University students (Hambrick, Turk, Heimberg, Schneier, \& Liebowitz, 2003). Studies have supported that lower levels of life satisfaction have been related to high anxiety (Bourland et al., 2000; Cook, Black, Rabins, \& German, 2000; Headey, Kelley, \& Wearing, 1993; Honkalampi, Saarinen, Hintikka, Virtanen, \& Viinamaeki, 1999). Perceived stress is useful in predicting life satisfaction (Matheny, Roque-Tovar, \& Curlette, 2008) and researchers have associated stress and life satisfaction among college students (Barnes \& Lightsey, 2005; Extremera, Duran, \& Rey, 2009; Matheny 
Roque-Tovar, \& Curlette, 2008; Schiffrin \& Nelson, 2010; Weinstein \& Laverghetta, 2009).

In our research we used the concept of empathy as used by Davis $(1980,1994)$ who divides empathy into four elements: perspective-taking (the tendency to recognize and participate in the psychological point of view of others), empathic concern (the concern and feelings of empathy towards others), personal distress (the feelings (anxiety, etc.) or the distress one experiences in stressful situations or when other are stressed), and fantasy ('respondents' tendencies to transpose themselves imaginatively into the feelings and actions of fictitious characters in books, movies, and plays") (Davis, 1983: p. 114). The reason for this decision was based on the thought that it is the most commonly used model to measure individual differences in empathy (Pulos, Elison, \& Lennon, 2004). Therefore, University years are considered to be as one of the most stressful periods (Cress \& Lampman, 2007). So high life satisfaction is associated with social assertiveness and good empathy attributes (Veenhoven, 1996).

In sum, life satisfaction is a concept attributed as valuable by college students, and it is highly correlated with both psychological/affective variables and some daily life events. Therefore, it is an important indicators of psychological health.

The present study is a continuation from the pilot study published in (Paschali \& Tsitsas, 2010). In the present work we increased the sample size i.e., from 200 to 410 undergraduate students, we also explore additional factors to anxiety such as assertiveness and empathy. We expect to find similar results to our pilot study, in relation to anxiety and life satisfaction (i.e. high in life satisfaction low in anxiety); in addition we also expect that life satisfaction to be associated with assertiveness, high empathy and low anxiety. Furthermore we explore the associations between gender, places of growth, between $1^{\text {st }}$ and $4^{\text {th }}$ year undergraduate University students, with factors such as anxiety, life satisfaction, assertiveness and empathy.

\section{Method}

\subsection{Participants}

The sample was conducted from two Universities in Athens during the academic period 2014-2015. Students indicated their wish to participate in research voluntarily after an advertised announcement within the Universities premises. The questionnaires were given to students to complete during their Fall and Spring semester studies. The students signed a consent form with for participation in the study. In this study, out of 500 students who were approached, 400 (80\%) completed the questionnaire. It considered to be an excellent response rate. Fincham (2008) states: "Response rates approximating 60\% for most research should be the goal of researchers" (p. 1). According to Cohen's guidelines concerning a two-tailed t-test for independent samples, used in this study, a sample size of 400 (or more) is sufficient in order to achieve a power of $80 \%$ assuming a small effect size of 0.20 and a significance level of 0.05 . That sample size is also adequate for the ANOVA test, also used in the present study. 


\subsection{Measures}

For the purposes of the research's goals the following psychometric tools were used:

1) The Life Satisfaction Index. Developed by Neugarten, Havighurst, and Tobin (1961) as a short, easily administered measure of adults' feelings of satisfaction with their lives. The Greek version was developed by Malikiosi-Loizos \& Anderson (1994), for a sample of 36 bilingual Greek University women. The internal reliability was 0.78 .

Rathus Assertiveness Schedule. The specific scale was developed by Rathus (1973) in order to measure people's assertiveness level (e.g. if a famed and respected lecturer makes a comment which I think is incorrect, I will have the audience hear my point of view as well). The Greek version of the scale (Malikiosi-Loizos \& Tsitsas, 2012) was comprised using the method of backward translation and the reliability was very good $(\alpha=0.86)$ in a sample of 400 Greek students.

2) Interpersonal Reactivity Index (IRI) (Davis, 1980, 1983) is a multidimensional scale of 28 self-report items. It assumes that empathy consists of separate but related constructs and measures both cognitive and affective aspects of empathy. The IRI has four subscales: perspective taking (IRIpt), fantasy scale (IRIfs), empathic concern (IRIec), personal distress (IRIpd). The Greek version (Malikiosi-Loizos \& Tsitsas, 2012), of the scale was comprised using the method of backward translation. IRI has demonstrated good intrascale and test-retest reliability, and convergent validity in a sample of 400 Greek students ( $\alpha=0.71$ to 0.82 for all scales).

3) The State-Trait Anxiety Inventory (STAI) (Spielberger, Gorush, \& Lushene, 1970; Liakos \& Giannitisi, 1984). The STAI consists of two separate self-report scales for measuring State and Trait anxiety separately. Both scales consist of 20 test items. It was administered to all participants.

\subsection{Statistical Analysis}

Normality of distribution was evaluated through the Shapiro-Wilk test. Continuous variables are presented as mean \pm standard deviation (SD) and categorical variables are summarized as relative frequencies (\%). Associations between categorical variables were tested by the use of contingency tables and the calculation of chi-square tests without the correction of continuity. Associations between continuous variables and binary variables were evaluated through Student's t-test. Two way analysis of variance (two-way ANOVA) was used to evaluate whether the year interacts with each one of the rest of characteristics (i.e., gender, students job, anxiety, fantasy, distress etc.). When statistically significantly two-way interaction terms were detected, stratified univariate analysis by year was performed in order to examine the association of each characteristic with the life satisfaction for students of the $1^{\text {st }}$ and $4^{\text {th }}$ year, respectively. Finally, multiple linear regression was performed in order to identify the characteristics independently associated with the life satisfaction. In particular, the stepwise procedure was used. 
A probability value of $5 \%$ considered as statistically significant. The SPSS v. 20.0 statistical package was used for the analysis of the present data (SPSS Inc, Chicago, Il, USA).

\section{Results}

The sample consisted of $\mathrm{N}=410$ students, 188 men (45.8\%) and 222 women (54.2\%). The average age of the total sample was 19.9 years old, the standard deviation 2.4 with a range fluctuated from 18 to 23 . As far as men were concerned the average age was 21.11 and for women the average was 21.09. 205 of the participants were from the $1^{\text {st }}$ year and 205 students from the $4^{\text {th }}$ year.

The mean \pm standard deviation of the "life satisfaction score" was $4.3 \pm 0.5$. Moreover, the majority of participants (63.4\%) were found to have low "life satisfaction". Table 1 illustrates the percent of students with low and high life satisfaction based on several other characteristics of students. It can be observed that the percent of students with high life satisfaction is statistically significantly higher among those that grew up in urban and semiurban regions compared to those that grew up in other regions $(p=0.007)$ and the unemployed compare to their counterparts $(p=0.048)$. There was a statistically significant association between state anxiety and life satisfaction levels, $\chi^{2}(1)=4.50, p=0.035$. Moreover, there was a weak association between state anxiety and life satisfaction levels, $\varphi=0.15, p=.035$. The percentage of students with high life satisfaction was statistically significantly higher among those with low state anxiety $(p=0.035)$ but not with low trait anxiety $(p=0.30)$. In the empathy scale, high life satisfaction score was statistically significantly higher among those with low fantasy ( $p=$ $0.002)$, low perspective taking $(p=0.009)$ and low distress $(p=0.013)$. No significant association was detected between the life satisfaction of students and the year of studies $(p=0.538)$ or the assertiveness scale $(p=0.531)$. However, treating the life satisfaction score as a continuous variable, it was found that the mean score $(4.2 \pm 0.4)$ of students of the $1^{\text {st }}$ year was statistically significantly lower compared to students of the $4^{\text {th }}$ year $(4.4 \pm 0.6, p=0.005)$.

Two-way ANOVA showed that the two-way interaction between the year and students' sex $(p<0.001)$, students' job $(p=0.006)$, state of anxiety $(p=0.034)$, fantasy scale $(p=0.045)$, and region where the students grew up $(p<0.001)$ were statistically significant. Then, stratified analysis by year was performed in order to examine the association of the aforementioned characteristics with the life satisfaction. Table 2 and Table 3 present the results of the stratified univariate analysis by year.

Regarding the association of students' sex with life satisfaction, it was observed that this association was statistically significant in both years $(p=0.002$ and $p=0.001$ for the $1^{\text {st }}$ and $4^{\text {th }}$ year, respectively). However, it was found that women are more life satisfied compared to men among $1^{\text {st }}$-year students (Table 2 ) as beta $=0.206$, while the opposite was detected among $4^{\text {th }}$-year students (Table 3 ) as beta $=-0.375$. 
Table 1. The percent of students with low and high life satisfaction based on several other characteristics of students.

\begin{tabular}{|c|c|c|c|}
\hline & \multicolumn{2}{|c|}{ Life satisfaction } & \multirow{2}{*}{$p$-valu } \\
\hline & Low & High & \\
\hline \multicolumn{4}{|l|}{ Gender } \\
\hline Male & $62.4 \%$ & $37.6 \%$ & 0.811 \\
\hline Female & $63.7 \%$ & $36.3 \%$ & \\
\hline \multicolumn{4}{|l|}{ Year } \\
\hline $1^{\mathrm{st}}$ & $64.9 \%$ & $35.1 \%$ & 0.538 \\
\hline $4^{\text {th }}$ & $62.0 \%$ & $38.0 \%$ & \\
\hline Age (Years) & $19.9 \pm 2.4$ & $19.9 \pm 1.9$ & 0.947 \\
\hline \multicolumn{4}{|l|}{ Place of growth } \\
\hline Big city & $66.8 \%$ & $33.2 \%$ & \\
\hline Urban & $50.6 \%$ & $49.4 \%$ & 0.007 \\
\hline Semiurban & $56.9 \%$ & $43.1 \%$ & \\
\hline Rural & $78.9 \%$ & $21.1 \%$ & \\
\hline \multicolumn{4}{|l|}{ Job } \\
\hline Yes & $69.8 \%$ & $30.2 \%$ & 0.048 \\
\hline No & $60.0 \%$ & $40.0 \%$ & \\
\hline Assertiveness & $0.74 \pm 23.1$ & $2.80 \pm 21.0$ & 0.531 \\
\hline \multicolumn{4}{|l|}{ State anxiety } \\
\hline Low & $60.9 \%$ & $39.1 \%$ & 0.035 \\
\hline High & $75.4 \%$ & $24.6 \%$ & \\
\hline \multicolumn{4}{|l|}{ Trait anxiety } \\
\hline Low & $55.4 \%$ & $44.6 \%$ & 0.303 \\
\hline High & $62.6 \%$ & $37.4 \%$ & \\
\hline \multicolumn{4}{|l|}{ Fantasy } \\
\hline Low & $48.1 \%$ & $51.9 \%$ & 0.002 \\
\hline High & $67.1 \%$ & $32.9 \%$ & \\
\hline \multicolumn{4}{|l|}{ Empathy } \\
\hline Low & $60.6 \%$ & $39.4 \%$ & 0.745 \\
\hline High & $62.3 \%$ & $37.7 \%$ & \\
\hline \multicolumn{4}{|l|}{ Perspective } \\
\hline Low & $48.3 \%$ & $51.7 \%$ & 0.009 \\
\hline High & $66.3 \%$ & $33.7 \%$ & \\
\hline \multicolumn{4}{|l|}{ Distress } \\
\hline Low & $38.1 \%$ & $61.9 \%$ & 0.013 \\
\hline High & $64.9 \%$ & $35.1 \%$ & \\
\hline
\end{tabular}


Table 2. The results of simple linear regression for students of the $1^{\text {st }}$ year of the University.

\begin{tabular}{|c|c|c|c|}
\hline & $\beta$ & $95 \% \mathrm{CI}$ & $p$-value \\
\hline \multicolumn{4}{|l|}{ Gender } \\
\hline Male & Reference category & - & - \\
\hline Female & 0.206 & $0.078-0.334$ & 0.002 \\
\hline \multicolumn{4}{|c|}{ Place of growth } \\
\hline Rural & Reference category & - & - \\
\hline Big city & 0.486 & $0.219-0.752$ & $<0.001$ \\
\hline Urban & 0.445 & $0.172-0.719$ & 0.002 \\
\hline Semiurban & 0.749 & $0.460-1.037$ & $<0.001$ \\
\hline \multicolumn{4}{|l|}{ Job } \\
\hline Yes & Reference category & - & - \\
\hline No & 0.340 & $0.178-0.502$ & $<0.001$ \\
\hline \multicolumn{4}{|l|}{ State anxiety } \\
\hline Low & Reference category & - & - \\
\hline High & -0.125 & $-0.250-0.000$ & 0.05 \\
\hline \multicolumn{4}{|l|}{ Fantasy } \\
\hline Low & Reference category & - & - \\
\hline High & 0.205 & $0.034-0.376$ & 0.019 \\
\hline
\end{tabular}

Table 3. The results of simple linear regression for students of the $4^{\text {th }}$ year of the University.

\begin{tabular}{|c|c|c|c|}
\hline & $\beta$ & $95 \% \mathrm{CI}$ & $p$-value \\
\hline \multicolumn{4}{|l|}{ Gender } \\
\hline Male & Reference category & - & - \\
\hline Female & -0.375 & $-0.587-(-0.162)$ & 0.001 \\
\hline \multicolumn{4}{|c|}{ Place of growth } \\
\hline Rural & Reference category & - & - \\
\hline Big city & 0.115 & $-0.120-0.351$ & 0.335 \\
\hline Urban & 0.258 & $-0.061-0.577$ & 0.113 \\
\hline Semiurban & -0.241 & $-0.590-0.109$ & 0.174 \\
\hline \multicolumn{4}{|l|}{ Job } \\
\hline Yes & Reference category & - & - \\
\hline No & 0.001 & $-0.164-0.163$ & 0.997 \\
\hline \multicolumn{4}{|l|}{ State anxiety } \\
\hline Low & Reference category & - & - \\
\hline High & 0.169 & $-0.071-0.410$ & 0.167 \\
\hline \multicolumn{4}{|l|}{ Fantasy } \\
\hline Low & Reference category & - & - \\
\hline High & -0.063 & $-0.252-0.126$ & 0.511 \\
\hline
\end{tabular}


On the other hand, the rest of the characteristics such as the place of living, the employment and anxiety, were found to be significantly associated with life satisfaction only among $1^{\text {st }}$ year students. More specific, it was detected that the life satisfaction of students that grew up in big cities, urban and semi-urban regions were significantly higher compared those who grew up in rural regions (Table 2). Moreover, the life satisfaction of students who do not work and those with high fantasy was found to be significantly higher compared to those who work and those with low fantasy, respectively. Finally, the life satisfaction of students with high state anxiety was found to be significantly lower compared to those with low state anxiety.

Table 4 presents the factors independently associated with the life satisfaction among the $1^{\text {st }}$ year and 4 th year students. We observe that only the sex as beta $=$ 0.231 , whether students work or not as beta $=0.320$, the region where the students grew up as well as the distress as beta $=-0.244$ were significantly associated with the life satisfaction.

\section{Discussion}

The transition from school to College requires developing skills for maintaining the independence and self-sufficiency and for managing new tasks is considered anxiety-provoking among undergraduate students (Zirkel, 1992). Some explanations were established on the role-strain perspective which assumes that expansion of the number and types of role demands may result in a more stressful life and less life satisfaction (Barnett \& Baruch, 1985).

Table 4. Factors independently associated with the life satisfaction among $1^{\text {st }}$ year students and $4^{\text {th }}$ year students; Results from the stepwise linear regression.

\begin{tabular}{|c|c|c|c|}
\hline & $\beta$ & $95 \% \mathrm{CI}$ & $p$-value \\
\hline \multicolumn{4}{|l|}{ Sex } \\
\hline Male & Reference category & - & - \\
\hline Female & 0.231 & $0.115-0.347$ & $<0.001$ \\
\hline \multicolumn{4}{|l|}{ Job } \\
\hline Yes & Reference category & - & - \\
\hline No & 0.320 & $0.170-0.469$ & $<0.001$ \\
\hline \multicolumn{4}{|l|}{ Distress } \\
\hline Low & Reference category & - & - \\
\hline High & -0.244 & $-0.435-(-0.052)$ & 0.013 \\
\hline \multicolumn{4}{|c|}{ Region grew up } \\
\hline Rural & Reference category & - & - \\
\hline Big city & 0.603 & $0.355-0.852$ & $<0.001$ \\
\hline Urban & 0.570 & $0.313-0.827$ & $<0.001$ \\
\hline Semiurban & 0.746 & $0.477-10.015$ & $<0.001$ \\
\hline
\end{tabular}


According to the results of this study it can be suggested that students who have low anxiety scores have more life satisfaction than students with high stress scores, a finding that agrees with other research studies (i.e. Bourland et al., 2000; Cook et al., 2000; Parkerson, Broadhead, \& Tse, 1990) and also with our preliminary results (Paschali \& Tsitsas, 2010), documented that students who had higher levels of life satisfaction, reported lower levels of anxiety. Boa, Pan, Shi, and Ji (2013) in a research with 397 adults ages 18 to 65 found that increased levels of anxiety were negatively correlated with life satisfaction. Similarly, Lucas-Carrasco, Sastre-Garriga, Galan, Den Oudsten, and Power (2014) in their research and Warnecke, Baum, Peer, \& Goreczny (2014) found a negative correlation between anxiety and life satisfaction. Therefore, students with lower levels of life satisfaction experience higher anxiety. It seems that anxiety is increasing among college students something that is also supported by the American College Health Association (2000, 2009).

The fact that significant differences were found for the State condition and not the Trait could be explained by the characteristics of the participants. A physical and social environment (e.g. University) can be stressful for some students but outside University life, students can be more relaxed and happy (Anderson, 1988; Simons, Aysan, Thompson, Hamarat, \& Steele, 2002).

Furthermore failure to follow the tasks required from University studies, may result in life dissatisfaction (Schwartz, Coté, \& Arnett, 2005). According to the model of life-satisfaction (Campbell, Converse, \& Rodgers, 1976; Erikson, 1994), pleasant emotions stem from the satisfaction accompanying the perception that important "needs" have to be met or fulfilled (Frisch, Cornell, Villanueva, \& Retzlaff, 1992). Anxiety usually is associated with low life-satisfaction which may result from the inability to meet those needs required or expected in areas of life such as University or College years.

Some researchers show that there were no differences between female and male University students (Deniz, 2006), while some other researchers report gender differences in anxiety among undergraduates i.e. females score higher on anxiety than males (Chapell et al., 2005). In our pilot study (Paschali \& Tsitsas, 2010) for example, it was found that the majority of undergraduate students had low "life satisfaction" without any differences between the two sexes and first year students had less life satisfaction than $4^{\text {th }}$-year students. This is could be, because $1^{\text {st }}$-year students are in the transitional phase from school to college and life satisfaction can be strongly influenced by life events such as the years in college. It is speculated that students of higher ranked Universities have higher mean values of affective and overall life satisfactions (Nghiêm-Phú, 2013). In the present study however, one explanation could be that women are more life satisfied compared to men among $1^{\text {st }}$ year students, while the opposite was detected among $4^{\text {th }}$ year students (i.e. men are more life satisfied than women). One explanation of this finding could be that women use more emotion focused strategies than men and express their feelings more overtly than men (Garnefski, Teerds, Kraaij, Legerstee, \& van den Kommer, 2004; Hänninen \& Aro, 1996; 
Misra, McKean, West, \& Russo, 2000). As Ptacek, Smith, and Zanas (1992) found that male undergraduates reported, using problem-focused coping strategies, more frequently than females. In addition, Misra, \& Castillo (2004) found that gender differences also influence a student's perception and reaction to academic stressors. Women for example more often report "letting out their feelings", whereas men more often report "controlling their emotions, accepting the problem, not thinking about the situation, and engaging in problem-solving efforts" (Hyde \& Plant, 1995). Coping styles to stressors also differ by gender, when compared at similar levels of stress, women exhibit stress more overtly than males (Hyde \& Plant, 1995; Thomas \& Williams, 1991). It can be observed that the percent of students with high life satisfaction is statistically significantly higher among those that grew up in urban and semi-urban regions compared to those that grew up in other regions. One possible explanation could be that social support and social networks enhance students' college-adjustment. Social networks are considered to be less connected in urban and semi-urban regions (Lamothe et al., 1995; Pratt et al., 2000).

No significant associations were detected between life satisfaction scores and assertiveness scale, independently of the year of study. At first life satisfaction is associated with personal identity, intimate relationships (Roisman, Masten, Coatsworth, \& Tellegen, 2004) and independence and effort to accomplish these goals. Herringer (1998), found a correlation between assertiveness and life satisfaction in males but not in females. Another interesting finding was that, high life satisfaction was statistically significantly higher among those with low fantasy, low perspective taking and low distress. Empathy plays a role in the prevention of loneliness and burnout, and in the promotion of life satisfaction. Emotional empathy was negatively related to life satisfaction.

Finally determining the variables that play a crucial role during undergraduate years, will assist psychological counselling and guidance to University or College students. Counselling techniques can be more tailored made to the needs of undergraduate students. It is important to explore interventions that will aim to assist young men and women during University years to adjust to the demands of University or College life. Furthermore, taking into consideration variables such as gender differences might play an important role on coping strategies and reactions to stress.

\section{Limitations of the Present Study}

One of the limitations of the present study is that the specific sample relates to the population of the $1^{\text {st }}$ and $4^{\text {th }}$-year students of the specific two Universities and is not a representative sample of all the first and fourth year students in the country. Therefore we cannot generalize the results to all $1^{\text {st }}$ and $4^{\text {th }}$-year students.

Another limitation is that the study has relied only on quantitative analysis of data and it would be have been interesting if qualitative methodology was additionally employed, in order to provide wider perspective to the present study. 


\section{Conclusion}

The present study contributes to the existing literature by looking at differences between $1^{\text {st }}$ and $4^{\text {th }}$-year students in relation to life satisfaction, anxiety, empathy $\&$ assertiveness. The results showed that women have more life-satisfaction as compared to men among $1^{\text {st }}$-year students. According to the results of this study it can be suggested that students who have low anxiety scores have higher life satisfaction than students with high stress scores.

Determining the relationship among anxiety and life satisfaction among University students will assist improving psychological counselling and guidance.

\section{Acknowledgements}

STAI-AD copyrighted 1968, 1977 Charles D. Spielberger. All Rights Reserved. Permission for use of Greek translation received from publisher Mind Garden, Inc., https://www.mindgarden.com/.

\section{Conflicts of Interest}

The authors declare no conflicts of interest regarding the publication of this paper.

\section{References}

American College Health Association (2000). American College Health Association National College Health Assessment: Reference Group Executive Summary.

American College Health Association (2009). American College Health Association National College Health Assessment Spring 2008 Reference Group Data Report (Abridged): The American College Health Association. Journal of American College Health, 57, 477-488. https://doi.org/10.3200/JACH.57.5.477-488

Anderson, S. A. (1988). Parental Stress and Coping during the Leaving Home Transition. Family Relations, 37, 160-165. https://doi.org/10.2307/584314

Arnett, J. J. (2000). Emerging Adulthood: Prospects for the 21st Century.

Barnes, P. W., \& Lightsey, O. R. (2005) Perceived Racist Discrimination, Coping, Stress, and Life Satisfaction. Journal of Multicultural Counseling and Development, 33, 48-61. https://doi.org/10.1002/j.2161-1912.2005.tb00004.x

Barnett, G. C., \& Baruch, O. K. (1985). Women's Involvement in Multiple Roles, Role Strain, and Psychological Distress. Journal of Personality and Social Psychology, 49, 135-145. https://doi.org/10.1037/0022-3514.49.1.135

Boa, X., Pan, W., Shi, M., \& Ji, M. (2013). Life Satisfaction and Mental Health in Chinese Adults. Social Behavior and Personality, 41, 1597-1604. https://doi.org/10.2224/sbp.2013.41.10.1597

Bourland, S. L., Stanley, M. A., Snyder, A. G., Novy, D. M., Beck, J. G., Averill, P. M., \& Swann, A. C. (2000). Quality of Life in Older Adults with Generalized Anxiety Disorder. Aging and Mental Health, 4, 315-323. https://doi.org/10.1080/713649960

Campbell, A., Converse, P., \& Rodgers, W. (1976). The Quality of American Life: Perceptions, Evaluations, and Satisfactions. New York: Russell Sage Foundation.

Chao, R. C. L. (2012). Managing Perceived Stress among College Students: The Roles of Social Support and Dysfunctional Coping. Journal of College Counseling, 15, 5-21. 
https://doi.org/10.1002/j.2161-1882.2012.00002.x

Chapell, M. S., Blanding, Z. B., Silverstein, M. E., Takahashi, M., Newman, B., Gubi, A. et al. (2005). Test Anxiety and Academic Performance in Undergraduate and Graduate Students. Journal of Educational Psychology, 97, 268-274. https://doi.org/10.1037/0022-0663.97.2.268

Chow, H. P. H. (2005). Life Satisfaction among University Students in a Canadian Prairie City: A Multivariate Analysis. Social Indicators Research, 70, 139-150. https://doi.org/10.1007/s11205-004-7526-0

Cook, J. M., Black, B. S., Rabins, P. V., \& German, P. (2000). Life Satisfaction and Symptoms of Mental Disorder among Older African American Public Housing Residents. Journal of Clinical Geropsychology, 6, 1-14. https://doi.org/10.1023/A:1009541822048

Cress, V. C., \& Lampman, C. (2007). Hardiness, Stress, and Health-Promoting Behaviors among College Students. Psi Chi Journal of Undergraduate Research, 12, 18-23. https://doi.org/10.24839/1089-4136.JN12.1.18

Darling, C. A., McWey, L. M., Howard, S. N., \& Olmstead, S. B. (2007). College Student Stress: The Influence of Interpersonal Relationships on Sense of Coherence. Stress and Health, 23, 215-229. https://doi.org/10.1002/smi.1139

Davis, M. H. (1980). A Multidimensional Approach to Individual Differences in Empathy. JSAJ Catalog of Selected Documents in Psychology, 10, 85.

Davis, M. H. (1983). Measuring Individual Differences in Empathy: Evidence for a Multidimensional Approach. Journal of Personality \& Social Psychology, 44, 113-126. https://doi.org/10.1037/0022-3514.44.1.113

Davis, M. H. (1994). Empathy: A Social Psychological Approach. Boulder, CO: Westview Press, Inc., A Division of Harper Collins Publishers, Inc.

Deniz, M. E. (2006). The Relationships among Coping with Stress, Life Satisfaction, Decision-Making Styles and Decision Self-Esteem: An Investigation with Turkish University Students. Social Behavior and Personality, 34, 1161-1170. https://doi.org/10.2224/sbp.2006.34.9.1161

Diener, E. (2000). Subjective Well-Being: The Science of Happiness, and a Proposal for National Index. American Psychologist, 55, 34-43. https://doi.org/10.1037/0003-066X.55.1.34

Diener, E., Lucas, R. E., \& Oishi, S. (2002). Subjective Well-Being: The Science of Happiness and Life Satisfaction. In C. R. Snyder, \& S. J. Lopez (Eds.), Handbook of Positive Psychology (pp. 63-73). New York: Oxford University Press.

Ellis, J., \& Hartley, C. (2005). Managing and Coordinating Nursing Care (4th ed., pp. 7-8, 18, 136). Philadelphia, New York, London: Lippincott Williams and Wilkins Co.

Erikson, E. (1994). Identity and the Life Cycle. New York: WW Norton \& Company.

Extremera, N., Durán, A., \& Rey, L. (2009) The Moderating Effect of Trait Meta-Mood and Perceived Stress on Life Satisfaction. Personality \& Individual Differences, 47, 116-121. https://doi.org/10.1016/j.paid.2009.02.007

Fincham, J. E. (2008). Response Rates and Responsiveness for Surveys, Standards, and the Journal. American Journal of Pharmaceutical Education, 72, 43. https://doi.org/10.5688/aj720243

Frisch, M. B., Cornell, J., Villanueva, M., \& Retzlaff, P. J (1992). Clinical Validation of the Quality of Life Inventory: A Measure of Life Satisfaction for Use in Treatment Planning and Outcome Assessment. Psychological Assessment, 4, 92-101.

https://doi.org/10.1037/1040-3590.4.1.92

Garnefski, N., Teerds, J., Kraaij, V., Legerstee, J., \& van den Kommer, T. (2004). Cogni- 
tive Emotion Regulation Strategies and Depressive Symptoms: Differences between Males and Females. Personality and Individual Differences, 36, 267-276. https://doi.org/10.1016/S0191-8869(03)00083-7

Hambrick, J., Turk, C., Heimberg, R. G., Schneier, F. R., \& Liebowitz, M. (2003). Experience of Disability and Quality of Life in Social Anxiety Disorder. Depression and Anxiety, 18, 46-50. https://doi.org/10.1002/da.10110

Hänninen, V., \& Aro, H. (1996). Sex Differences in Coping and Depression among Young Adults. Social Science \& Medicine, 43, 1453-1460. https://doi.org/10.1016/0277-9536(96)00045-7

Headey, B. W., Kelley, J., \& Wearing, A. J. (1993). Dimensions of Mental Health: Life Satisfaction, Positive Affect, Anxiety, and Depression. Social Indicators Research, 29, 63-72. https://doi.org/10.1007/BF01136197

Herringer, L. G. (1998). Facets of Extraversion Related to Life Satisfaction. Personality and Individual Differences, 24, 731-733. https://doi.org/10.1016/S0191-8869(97)00194-3

Honkalampi, K., Saarinen, P., Hintikka, J., Virtanen, V., \& Viinamaeki, H. (1999). Factors Associated with Alexithymia in Patients Suffering from Depression. Psychotherapy \& Psychosomatics, 68, 270-275. https://doi.org/10.1159/000012343

Hyde, J. S., \& Plant, E. A. (1995). Magnitude of Psychological Gender Differences: Another Side of the Story. American Psychologist, 50, 159-161. https://doi.org/10.1037/0003-066X.50.3.159

Lamothe, D., Currie, F., Alisat, S., Sullivan, T., Pratt, M., Pancer, S. et al. (1995). Impact of a Social Support Intervention on the Transition to University. Canadian Journal of Community Mental Health, 14, 167-180. https://doi.org/10.7870/cjcmh-1995-0023

Lange, A., \& Jakubowski, P. (1976). Responsible Assertive Behavior: Cognitive/Behavioral Procedures for Trainers. Champaign, IL: Research Press.

Liakos, A., \& Giannitsi, S. (1984). The Reliability and Validity of the Greek Version of Spielberger's, State and Trait Anxiety Inventory. Encephalos, 21, 71-76.

Lucas-Carrasco, R., Sastre-Garriga, J., Galán, I., Den Oudsten, B. L., \& Power, M. J. (2014). Preliminary Validation Study of the Spanish Version of the Satisfaction with Life Scale in Persons with Multiple Sclerosis. Disability and Rehabilitation, 36, 1001-1005. https://doi.org/10.3109/09638288.2013.825650

Malikiosi-Loizos, M., \& Anderson, L. (1994). Reliability of a Greek Translation of the Life Satisfaction Index. Psychological Reports, 74, 1319-1322. https://doi.org/10.2466/pr0.1994.74.3c.1319

Malikiosi-Loizos, M., \& Tsitsas, G. (2012). Interpersonal Reactivity Index. In A. Stalikas, S. Triliva, \& P. Roussi (Eds.), Psychometric Instruments in Greece (2nd ed). Athens: Pedio.

Matheny, K. B., Roque-Tovar, B. E., \& Curlette, W. L. (2008). Perceived Stress, Coping Resources, and Life Satisfaction among U. S. and Mexican College Students: A Crosscultural Study. Anales de Psicología, 24, 49-57.

Misra, R., \& Castillo, L. (2004). Academic Stress among College Students: Comparison of American and International Students. International Journal of Stress Management, 2, 132-148. https://doi.org/10.1037/1072-5245.11.2.132

Misra, R., McKean, M., West, S., \& Russo, T. (2000). Academic Stress of College Students: Comparison of Student and Faculty Perceptions. College Student Journal, 34, 236-245.

Neugarten, B. L., Havighurst, R. J., \& Tobin, S. S. (1961). The Measurement of Life Satisfaction. Journal of Gerontology, 16, 134-143. https://doi.org/10.1093/geronj/16.2.134 
Nghiêm-Phú, B. (2013). On an Integrated Scale of the Life Satisfaction Construct. In Conference Proceedings of the 2013 International Symposium on Business, Banking, Marketing and Economy (ISBBME), and Annual Conference on Management and Social Science (ACMASS) (pp. 90-97). Taipei: ISBBME-ACMASS.

Parkerson, G. R., Broadhead, W. E., \& Tse, C.-K. J. (1990). The Duke Health Profile, a 17-Item Measure of Health and Dysfunction. Medical Care, 28, 1056-1072. https://doi.org/10.1097/00005650-199011000-00007

Paschali, A., \& Tsitsas, G. (2010). Stress and Life Satisfaction among University Students-A Pilot Study. Annals of General Psychiatry, 9, S96. https://doi.org/10.1186/1744-859X-9-S1-S96

Pratt, M., Hunsberger, B., Pancer, S., Alisat, S., Bowers, C., Mackey, K. et al. (2000). Facilitating the Transition to University: Evaluation of a Social Support Discussion Intervention Program. Journal of College Student Development, 41, 427-441.

Ptacek, J. T., Smith, R. E., \& Zanas, J. (1992). Gender, Appraisal, and Coping: A Longitudinal Analysis. Journal of Personality, 60, 747-770. https://doi.org/10.1111/j.1467-6494.1992.tb00272.x

Pulos, S., Elison, J., \& Lennon, R. (2004). The Hierarchical Structure of the Interpersonal Reactivity Index. Social Behavior and Personality, 32, 355-360. https://doi.org/10.2224/sbp.2004.32.4.355

Rathus, S. A. (1973). A 30-Item Schedule for Assessing Assertive Behavior. Behavior Therapy, 4, 398-406. https://doi.org/10.1016/S0005-7894(73)80120-0

Rickinson, B. (1998). The Relationship between Undergraduate Student Counselling and Successful Degree Completion. Studies in Higher Education, 23, 95-102. https://doi.org/10.1080/03075079812331380522

Roberts, R., \& Zelenyanski, C. (2002). Degrees of Debt. In N. Stankley, \& J. Manthorpe (Eds.), Students' Mental Health Needs Problems and Responses. London: Jessica Kinsley.

Roisman, G. I., Masten, A. S., Coatsworth, J. D., \& Tellegen, A. (2004). Salient and Merging Developmental Tasks in the Transition to Adulthood. Child Development, 75, 123-133. https://doi.org/10.1111/j.1467-8624.2004.00658.x

Schiffrin, H. H., \& Nelson, S. K. (2010). Stressed and Happy. Investigating the Relationship between Happiness and Perceived Stress. Journal of Happiness Studies, 11, 33-39. https://doi.org/10.1007/s10902-008-9104-7

Schwartz, S., Coté, J., \& Arnett, J. (2005). Identity and Agency in Emerging Adulthood. Youth \& Society, 37, 201. https://doi.org/10.1177/0044118X05275965

Simons, C., Aysan, F., Thompson, D., Hamarat, E., \& Steele, D. (2002). Coping Resource Availability and Level of Perceived Stress as Predictors of Life Satisfaction in a Cohort of Turkish College Students-Statistical Data Included. College Student Journal, 36, 129-141.

Spielberger, C. D., Gorsuch, R. L., \& Lushene, R. (1970). The State-Trait Anxiety Inventory. Palo Alto, CA: Consulting Psychologists Press.

Thomas, S. P., \& Williams, R. L. (1991). Relationships among Perceived Stress, Trait Anger, Modes of Anger Expression and Health Status of College Men and Women. Resources in Education, ERIC Document Reproduction Service No. ED 326808.

Veenhoven, R. (1996). The Study of Life Satisfaction. In W. E. Saris, R. Veenhoven, A. C. Scherpenzeel, \& B. Bunting (Eds.), A Comparative Study of Satisfaction with Life in Europe (pp. 11-48, Chapter 1). Budapest: Eötvös University Press.

Warnecke, A., Baum, C., Peer, J., \& Goreczny, A. (2014). Intercorrelations between Indi- 
vidual Personality Factors and Anxiety. College Student Journal, 48, 23-33.

Weinstein, L., \& Laverghetta, A. (2009). College Student Stress and Satisfaction with Life. College Student Journal, 43, 1161-1162.

Zirkel, S. (1992). Developing Independence in a Life Transition: Investing the Self in the Concerns of the Day. Journal of Personality and Social Psychology, 62, 506-521.

https://doi.org/10.1037/0022-3514.62.3.506 